\title{
COAL MINING AND THE ENVIRONMENTAL IMPACT OF ACID MINE DRAINAGE (AMD): A REVIEW
}

\author{
T. I. Ojonimi ${ }^{1,}{ }^{*}$, F. Asuke ${ }^{2}$, M. A. Onimisi ${ }^{3}$, C. Y. Onuh ${ }^{4}$ and N. Tshiongo-Makgwe ${ }^{5}$ \\ 1, DePartment of Mining Engineering, University of Jos, Plateau StaTe, NIGERIA \\ 2, Dept. Of Metallurgical \& Materials Engineering, Ahmadu Bello Univ., Zaria, Kaduna State, Nigeria \\ 3, DePARTMENT OF Mining ENGINEERING, University OF RWANDA, KigALI, RWANDA. \\ 4, Department of Petroleum Engineering, Covenant University, Otta, Ogun State, Nigeria. \\ 5, DePARTMENT OF METALLURGY, UNIVERSITY OF JOHANNESBURG, SOUTH AFRICA \\ E-mail addresses: ${ }^{1}$ t.ojonimi@gmail.com, ${ }^{2}$ asukef@gmail.com, ${ }^{3}$ matflo65@yahoo.com, \\ ${ }^{4}$ charles.onuh@covenantuniversity.edu.ng, 5 ntshiogo@uj.ac.za
}

\begin{abstract}
In spite of the growing global initiatives towards achieving clean energy, coal remains a dominant source of electricity generation, a fuel for iron and steel production, an important entity among road construction materials and a commodity for foreign exchange earnings for many nations. Coal mining from old and active sites remains a source of an environmental problem described as acid mine drainage (AMD). AMD is produced when sulfide present in waste rocks or tailings in coal mines reacts with air and water in a microbes facilitated oxidation to form solutions with high acidity. The acids formed by these chemical and biological conditions further release heavy metals present in the host rock in concentrations higher than are acceptable by environmental standards (pb;0.01, $\mathrm{Zn} ; 5, \mathrm{Cu} ; 2, \mathrm{Fe} ; 0.3 \mathrm{mg} / \mathrm{l}$ as prescribed by WHO and Encyclopedia of Environmental Science,2000) such that soils, surface and underground waters are contaminated. Consequently, the human population which derives her livelihood in the mine zones, in form of crop production and fishing/modern aquaculture is endangered by terminal health diseases. This article aims at bringing forth, the urgent need to work towards achieving goal six of the United Nations Sustainable Development Goals, 2030 (SDGs-6) which is clean water and sanitation while enriching the knowledge repository of the environmental problem for the purpose of teaching, research, community services and policy making. An overview of AMD menace, variables which influence its formation, selected areas that have been impacted, and a brief analysis of its treatment cost have been discussed with a list of concluding remarks in the paper.
\end{abstract}

Keywords: Coal, Mining, Environmental, AMD

\section{GENERAL OVERVIEW OF AMD}

The exploitation of minerals from the earth, represents one of man's early areas of civilization [1]. No nation experiences significant advances in technology and diversification of economy with the associated increases in foreign exchange and creation of jobs for her populace without mining. It is on this premise, for instance, that researchers, investors and the government view mining and processing of local coal deposits as a great potential for driving full scale operation of the Ajaokuta Iron Steel Company in Nigeria $[2,3]$. Now, with the global awareness and quest for introduction of stringent environmental regulations, profitability of mines in operation as well as approval of applications for new mines licenses will depend on the impact of effluents from these mines on the receiving downstream waters. The quality of water and soils in mine zones is influenced by acid mine drainage (AMD). AMD refers to stream of acidic effluent from a sulfide-rich

* Corresponding author, tel: +234- $706-517-0928$ 
mines or processing facilities and is formed as a result of particles oxidation by water and air [4, 5]. AMD forms age long pollution streams and soils leading to distortion of crops growth, destruction of aquatic life and shortening of design lifespans of civil infrastructures such as water reticulation networks and bridges by corroding them [6]

The rate at which AMD is generated defers from one sulfide mineral to another. For instance, crystalline pyrite (FeS) oxidises at a slower rate when compared with Marcasite (FeS) [7]. It is worthy of note that marcasite shares similarity with pyrite in terms of physical appearance and chemical composition but differ in crystallinity; while marcasite is characterized by an orthorhombic structure, pyrite is isometric [8]. The current discussion however, focuses on pyrite oxidation which has several unique characteristics that can be further explained by a convoy of complex chemical reactions as shown in equations 1-7 [9]

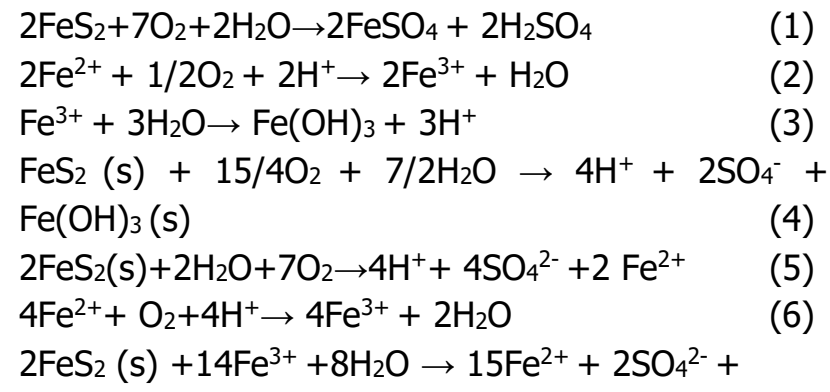

Pyrite $\left(\mathrm{FeS}_{2}\right)$ oxidation generally imparts acidity. In open pit mines which are characterized by high concentrations of atmospheric oxygen $\left(\mathrm{O}_{2}\right)$ and hydrogen $\left(\mathrm{H}^{+}\right)$, the condition provides for oxidation of $\left(\mathrm{Fe}^{2+}\right)$ to $\left(\mathrm{Fe}^{3+}\right)$ (equation 2). Oxidation of $\mathrm{Fe}^{3+}$ (equation 7) imparts the highest acidity as indicated by 16 molecules of hydrogen ion.

Waters running over limestone rocks in the coal catchment can resist little alterations in $\mathrm{pH}$ by developing a system of bicarbonate buffering at normal conditions of undisturbed coal layers. At this stage, the initiation and mobilization of AMD is so insignificant to constitute a threat to the recipient water and land environments. However, the oxidation reaction progressively increases when large quantities of the sulfide rocks are exposed via mining/processing and sometimes road construction. Thus, waste products derived from heap leaching technology, tailings ponds, waste rock piles, open mines pit walls and underground mine workings are all potential AMD generation sites. Streams emanating from these reactions sites could have $\mathrm{pH}$ of as low as 2.5 and less which can be overwhelming by further addition of acid and formation of $\left[\mathrm{Fe}(\mathrm{OH})_{3}\right]$ layers otherwise called yellow boy, under which crops never grow [6].

The understanding and prediction of AMD is based on the chemical reactions above. AMD prediction has become a global practice since several evolving technological advancements depend on mining with many old mines still requiring remediation [9]. The severity of this problem is more in old mines sites considering that nowadays, stringent environmental regulations stipulate the use of new technologies for in situ-monitoring, treatment and/or prevention of AMDs in active mines.

\section{AMD GENERATION VARIABLES}

This section highlights the array of variables responsible for formation of AMD. Understanding AMD is complex because the chemical reactions which characterize it depend on a bundle of several factors since no two mines, be it old or active are similar in topography, geochemistry and history of remediation. Strategies for remediation of abandoned and active mines could be optimised by understanding the influence of these factors on AMD Chemistry $[4,10]$.

\subsection{Effect of Particle Size}

The influence of particle size is a necessary parameter for the purpose of AMD prediction at bench scale. Prediction tests are conducted with small rock particles sizes and may not amount to accurate simulation of same for waste rocks generated on industrial scale. While trying to establish the effect of particle size on the rate of oxidation in actual mine conditions, Erguler and Ergueler [11] mentioned that sulfide mineral particles are subject to environmental factor of weathering. The research established that there is direct proportionality between AMD generation rate and particle surface area. This implies that oxidation of the exposed ores is a function of particle size distribution. Lapakko and Antoson [12] also reported the dependence of $\mathrm{pH}$ values of mine drainages on particle size variation where it was found that drains emanating from finer particles were more acidic. Having said this, the effect of particle size on AMD generation in waste rock piles differs from what obtains in tailings storage facilities. In waste rocks, AMD can be generated in particles averaging above $2 \mathrm{~cm}$ while in tailings impoundments, 
the process can take place in particles as low as $0.2 \mathrm{~mm}$ [7]

\subsection{Influence of mine type}

The determining parameter for AMD formation in open pit and underground mines is the presence of relative proportions of alumunium and iron, simply put as aluminium/iron ratio. This ratio is typically higher in open pit mines. The reason is that, in the open space, the coal sediment is more distorted which allows exposure of mineral particles surfaces for secondary interaction between sulfuric acid produced in AMD and alumino-silicates minerals such as feldspar present in the zone and consequent impartation of more acidity by the release of aluminuim ion $\left(\mathrm{Al}^{3+}\right)$ in high concentrations. Conversely, in underground mines, the mentioned secondary reaction is insignificant as atmospheric oxygen required to facilitate sufficient pyrite oxidation in the first instance is not abundant and therefore, the enclave is characterised by higher iron oxide concentration compared with alumina. In general, AMD occurs faster in open pit mines than in underground mines $[4,13]$

\subsection{Influence of microbial elements}

The interactions between microbes and pyrite generates AMD as the organisms form a community of acidophilic chemoautotrophs under waste rocks particles. Chemoautotrophs, refer to microorganisms which derive their sustenance from pyrite present in coal and atmospheric oxygen. Low pH condition increases by five folds, the rate of iron oxidation by the influence of these organisms with a corresponding increase in the rate of pyrite dissolution [14]. Since the influence of microorganisms on AMD generation is favoured by low $\mathrm{pH}$, one may safely mention that, presence of a neutralizing mineral such as calcite $\left(\mathrm{CaCO}_{3}\right)$ in the mine catchment could progressively decrease their activity. From the mineral processor's view point, this factor presents an advantage as the biological stage of selective sequential precipitation technology utilizes these microbes for recovery of metals dissolved in AMDs [15]. A summary of bacteria that play important roles in catalyzing pyrite oxidation is provided in Table 1.

\section{SELECTED AMD IMPACTED AREAS}

The impact of AMDs from Odagbo, Enugu and Lafiaobi coal mines in Kogi, Enugu and Nasarawa States, Nigeria respectively is reviewed in this section. A list of selected impacted areas in different continents is also presented in (Table 2)

\subsection{Odagbo}

An analysis of drains from Odagbo coal mine was conducted. The levels of lead, nickel, cobalt, chromium, mercury, zinc, arsenic and iron were reportedly investigated. Nickel, chromium and iron were found to be above the EPA acceptable environmental limits (0.0-1.0: Nickel, 0.0-0.05: chromium, irion: 0.0-0.3). The research concluded that the acid drainage if not curtailed could pollute the water bodies in the environment [16]. This supports the earlier findings by [17] which established lead, nickel and copper as metals found to have severely impacted the receiving soils and proposed the remediation of mines in the area.

\subsection{Enugu}

An analysis of water quality in Onyema and Okpala mine districts in Enugu, Southeast, Nigeria was reported by [18]. Mean values of heavy metals namely; Cadmium, Arsenic, Lead, Chromium were respectively reported as $0.33 \mathrm{mg} / \mathrm{l}, 0.06 \mathrm{mg} / \mathrm{l}$, $0.53 \mathrm{mg} / \mathrm{l}$ and $0.06 \mathrm{mg} / \mathrm{l}$ with mean $\mathrm{pH}$ values of 5.4 all of which exceeded the WHO permissible limits of $0.0-5.0 \mathrm{mg} / \mathrm{l}$ for all the metals identified. [19]. It was also reported that total dissolved solids (TDS) values ranging between 21.80 and $520 \mathrm{mg} / \mathrm{l}$ were below WHO permissible limits of $0.00-1500 \mathrm{mg} / \mathrm{l}$ but however injurious to the aquatic life in the catchment.

\subsection{Lafia-Obi}

An assessment of AMD as a potential environmental problem as a result of coal mining in Lafia-Obi, in Nasarawa State, North-Central Nigeria was conducted. The report envisaged environmental problems associated with the mining/beneficiation of the coal deposits and proposed the inclusion of detailed remediation plans in the environmental impact assessment (EIA) report [2].

Table 1: Growth Conditions of Sulfide Ore Bacteria

\begin{tabular}{lll}
\hline Bacteria & $\mathrm{PH}$ & Temperature $\left({ }^{\circ} \mathrm{C}\right)$ \\
\hline Thiobacilus thioparus & $4.5-10$ & $10-37$ \\
T.ferrooxidans & $0.5-6.0$ & $15-25$ \\
T.thiooxidans & $0.5-6.0$ & $10-37$ \\
T.neapolitanus & $3.0-8.5$ & $8-37$ \\
T.denitrificans & $4.0-9.5$ & $10-37$ \\
T.novellus & $5.0-9.2$ & $25-35$ \\
T.intermedius & $1.7-7.0$ & $25-35$
\end{tabular}




\begin{tabular}{lll}
\hline Bacteria & $\mathrm{PH}$ & Temperature $\left({ }^{\circ} \mathrm{C}\right)$ \\
\hline T.perometabolis & $2.8-6.8$ & $25-35$ \\
Sulfolobus acidocalderius & $2.0-5.0$ & $55-85$ \\
Desulfobivrio desulfuricans & $5.0-9.0$ & $10-45$
\end{tabular}

Source: [7]

It can be inferred that significant volumes of water and farm lands in the mentioned mine districts have been polluted and will require sufficient efforts in terms of technology, community participation and political will to address the issue.

\section{AMD REMEDIATION COST ANALYSIS}

In weighing AMD remediation costs, it is needful to mention the two major technologies adopted; one, is the passive remediation option which involves construction of limestone drain characterised by capacity for neutralising acid and curtailing excessive contamination of downstream areas. This passive technology option applies to abandoned mines which do not require maintenance cost, can be constructed without requiring men going inside the portal and saves labour cost. For instance, in constructing limestone drains of 20 by 100 feet nearly USD 70,000 was spent annually between year 1994 and 2000 which could have been more expensive if personnel cost was added [29]. In spite of this advantage, studies on the use of In situ limestone remediation system conducted reported that about USD4000 in savings was achieved for an active mine [30]. These scenarios indicate that, it is more economical to practice treatment while a mine is still active than leaving the burden of same on state environmental agencies to bear after closure. As per specific material costs, equation 8 can be used to measure the quantity of reagent needed per annum for AMD treatment. The conversion factor $Q$, determines the quantity of material needed annually for treatment. Neutralization Efficiency is the measure of the relative effectiveness of the reagent used [31].

$Q=\frac{\text { Conversion Factor }}{\text { Neutralisation Efficiency }} \times \operatorname{Acidity~}\left(\frac{\mathrm{mg}}{\text { annum }}\right)$

For instance, if $100 \mathrm{mg}$ of acid per annum is the amount of acid to be neutralized, then it can be estimated that $82 \mathrm{mg}$ of hydrated lime would be needed to neutralize the acidity of the waste stream. A summary of application of the formula is provided in Table 3

Table 2: A Collection of some AMD Impacted Areas World Wide

\begin{tabular}{|c|c|c|c|}
\hline Continent & Impacted Area/Mine & Length of Impacted area(Km)/Description & Source \\
\hline Africa & $\begin{array}{l}\text { Odagbo, Okaba, Enugu, Lafia-Obi } \\
\text { (Nigeria); West Rand Gold Field, } \\
\text { Witwatersrand (South Africa) }\end{array}$ & Unknown & $\begin{array}{l}{[2,16-} \\
20]\end{array}$ \\
\hline Europe & $\begin{array}{l}\text { Mines in the Bor Region (Serbia);Avoca } \\
\text { mine, Wicklow (Ireland); Aznalcollar } \\
\text { mine (Spain); Wheal Jane (England); } \\
\text { River Tinto (Spain), Libiola mine } \\
\text { (Italy) }\end{array}$ & $\begin{array}{l}\text { About } 130 \mathrm{~m} \text { of Lake Robule impacted due } \\
\text { to } 108 \text { tons of tailings dumps; Avoca mine } \\
\text { severely impacted with pH in the } \\
\text { neighborhood of } 3.5 \text {. }\end{array}$ & {$[21,23]$} \\
\hline $\begin{array}{l}\text { North } \\
\text { America }\end{array}$ & $\begin{array}{l}\text { Elizabeth , Gold King, Montana (USA); } \\
\text { Beach of Britannia, (Canada) }\end{array}$ & $\begin{array}{l}\text { AMD of upto } 60 \text { million gallons per day from } \\
\text { old forge borehole has impacted River } \\
\text { Lackawanna; Montana has impacted the } \\
\text { Clark Fork River and } 200 \mathrm{Km}^{2} \text { of land }\end{array}$ & {$[24,25]$} \\
\hline Oceania & $\begin{array}{l}\text { Mineral fields in the West Coast, } \\
\text { Brukunga mine, Zinc mine on the River } \\
\text { McArthur, Mount Morgan (Australia); } \\
\text { Ok Tedi (Paupa New Guinea); Grasberg } \\
\text { mine (Indonesia) }\end{array}$ & $\begin{array}{l}\text { OK Tedi mine impact on the environment is } \\
\text { described as disastrous }\end{array}$ & {$[26,28]$} \\
\hline
\end{tabular}

Table 3: Summary of AMD Treatment Chemicals

\begin{tabular}{lllll}
\hline Common Name & Chemical Name & Formula & Conversion Factor & Neutralisation Efficiency (\%) \\
\hline Limestone & Calcium Carbonate & $\mathrm{CaCO}_{3}$ & 1.00 & 30 \\
Hydrated Lime & Calcium Hydroxide & $\mathrm{Ca}(\mathrm{OH})_{2}$ & 0.74 & 90 \\
Quick Lime & Calcium Oxide & $\mathrm{CaO}$ & 0.56 & 90 \\
Soda ash & Sodium Carbonate & $\mathrm{Na}_{2} \mathrm{CO}_{3}$ & 1.06 & 60 \\
Caustic Soda: Solid & Sodium hydroxide & $\mathrm{NaOH}$ & 0.8 & 100
\end{tabular}




\begin{tabular}{lllll}
\hline Common Name & Chemical Name & Formula & Conversion Factor & Neutralisation Efficiency (\%) \\
\hline 20\% Liquid caustic & Sodium hydroxide & $\mathrm{NaOH}$ & 784 & 100 \\
$50 \%$ Liquid caustic & Sodium hydroxide & $\mathrm{NaOH}$ & 256 & 100 \\
Ammonia & Anhydrous Ammonia & $\mathrm{NH}_{3}$ & 3.4 & 100 \\
\hline
\end{tabular}

\section{CONCLUSION}

There are about 40 identified sulphide minerals, among which are pyrite (FeS), chalcopyrite (CuFeS 2$)$, sphalerite (ZnS), galena (PbS), cinnabar $(\mathrm{HgS})$ and Molybdenite $\left(\mathrm{MoS}_{2}\right)$ and AMD is bound to occur in their mines/processing facilities [9]. The case of pyrite, found in coal appears to have a wider impact on the environment for the obvious reasons of being a dominant electrical energy source, a fuel for iron/steel production and a road construction material. As contributions to solving the problem, the following points are proposed:

i. Prediction of future drainage chemistry should be routinely carried out on old and active coal and other sulphide-bearing mines

ii. Stringent environmental regulations should stipulate the use of modern and evolving technologies for in-situ monitoring, treatment and/or prevention of AMDs in active mines

iii. Establishment of Environmental Remediation Trust Fund (ERTF) from a fair but reasonable amount on mine operators' profits

iv. A repository for assessment and management of mine environments (RAMME) should be created

v. Environmental legislations should ensure that companies applying for mining licences indicate strong commitment to corporate social responsibility for the benefit of the local populace

vi. Conversion of old mines to tourist sites should be developed as sources of alternative employment opportunities for artisanal miners

\section{REFERENCES}

[1] Mamodu, A., Ojonimi, I.T., Apollos, S.S., Jacinta, O.N., Salome, W.H. and Enesi, A.A. Analyzing the Environmental Impacts and Potential Health Challenges Resulting from Artisanal Gold Mining in Shango Area of Minna, North-Central, Nigeria. Journal of Degraded and Mining Lands Management. Vol 5, No. 2, pp. 1055-1063, 2018

[2] Mallo, S.J. The Menace of Acid Mine Drainage: an impending challenge in the mining of lafia- obi coal, Nigeria. Continental J. Engineering Sciences. Vol 6, No.3, pp. 46 - 54, 2011

[3] Ako, T.A, Onoduku, U.S., Oke, S.A., Adamu, I.A., Ali, S.E., Mamodu, A. and Ibrahim, A.T. Environmental Impact of Artisanal Gold mining in Luku, Minna, Niger State, North Central Nigeria. Journal of Geosciences and Geomatic. Vol 1, pp. 28-37, 2012

[4] Pope, J., Newman, N., Craw, D., Trumm, D. and Rait, R. Factors that influence coal mine drainage chemistry West Coast, South Island, New Zealand, New Zealand Journal of Geology and Geophysics. Vol 53, pp.2-3, 2014

[5] Hanharan, G. Key Concepts in Environmental Chemistry. Chapter 3-Aqueos Chemistry. Elsevier Inc. pp 73-106, 2012

[6] Truța, R.M., Brăhaița, I.D., Pop, C.I., Baciu, C. and Popița, G. Batch experiment to test the limestone treatment on two types of acid mine water. AES Bioflux Vol.9, No.1, pp. 1-7, 2017

[7] USEPA. Technical Document of Acid Mine Drainage Prediction, Office of Solid Waste, United States Environmental Protection Agency, Washington D.C. p.5, 1994

[8] King, H.B. Marcasite: "Mineral Properties and Uses". https://Geology.com, Accessed on January 10, 2020

[9] Thorsten, C. Some Chemistry of Acid Mine Drainage. CR Scientific LLC. http://www.crscientific.com/article-amd.html, 2013

[10] Elis, M.J. Stockton Mine Water Treatment Plantthe removal of black water from the mangatini stream, New Zealand Conference, AusIMM, Wellington. pp 145-155, 2008

[11] Erguler, Z.A and Ergueler, G.K. The effect of Particle Size on Acid Mine Drainage Generation: Kinetic Column Tests. Minerals Engineering. Vol 76, pp. 154-167, 2015

[12] Lapakko, K.A. and Antoson, D.A. Pyrite Oxidation Rates from Humity Cell Testing of Greenstone Rock. In: th International Conference on Acid Rock Drainage (ICARD). St Louis MO., March 26-30, 2006

[13] Baker, B.J. and Benfield, J.F. Microbial Communities in Acid Mine Drainage. FEMS 
Microbiology, Ecology, Vol. 44, pp. 139152,2003

[14] Amils, R. Chemoautotroph. In: Garguad M. et al. (eds) Encyclopedia of Astrobiology. Springer, Berlin, Heidelberg. 2011

[15] Macingova, E. and Luptakova, A. (2012) Recovery of Metals from Acid Mine Drainage, Chemical Engineering Transactions, Vol 28, pp. 109-114, 2011

[16] Momoh, A., Rotji, E.P., Odewumi, S.C., Opuwari, M., Ojo, O.J. and Olorunyomi, A. Preliminary Investigation of Trace Elements in Acid Mine Drainage from Odagbo Coal Mine, North central, Nigeria. Journal of Environmental and Earth Science. Vol.7, No.1, pp 1-7, 2017

[17] Ameh, E.G. Multivariate Statistical Analyses and Enrichment of Heavy Metal Contamination of Soils around Okaba Coal Mine. AmericanEurasian Journal of Agronomy. Vol 6, No.1, pp.9-13, 2013

[18] Ezemokwe, D.E. and Madubuike, P.C. Impact of Coal Mining in Enugu Area of Nigeria on the Surrounding Water Quality. IOSR Journal of Environmental Science, Toxicology and Food Technology (IOSR-JESTFT). Vol 9, No. 12, Pp. 35-45, 2015

[19] "Publications on Water sanitation and healthWHO (2011)". www.who.int/water sanitation, Accessed on January 30, 2020

[20] Leifferink, M. Acid Mine Drainage: "The Environmental and Social Risks in the Witwatersrand Gold Fields". https://fse.org.za, Accessed on January 20, 2020.

[21] Petronijevic, N., Stankovic, S., Randovanovic, D., Sokic, M., Markovic, B., Stopic, S.R. and Kamberovic, Z. (2020). Application of the Flotation Tailings as an Alternative Material for an acid mine drainage remediation: A case Study of the extremely acidic Lake Rouble (Serbia). Metals. Vol 10, No. 1, p.16, 2020

[22] Wright, G., Misstear, B., Gallagher, B., Suilleabhain, D.O. and O'Connor, P. Avoca
Mines: Uncontrolled Acid Mine Drainage in Ireland. In: Proceedings of Mine Water and Environment. 1999 IMWA Conference, Spain

[23] Cidu, R. and Frau, F. (2007). Water in Mining Environments. Proceedings of International Mine Water Association Symposium, Cagliari, Sardinia, pp. 447, 2007.

[24] Brick, C.M. and Moore, J.N. Diel Variation of Trace Metals in the Upper Clark Fork River, Montana. Environmental Science and Technology. Vol 30, No. 6, pp.1953-1960, 1996

[25] Gibbons, B." Acid Mine Drainage". https://m.citizensvoice.com , Accessed on January, 182020

[26] Vincente-Beckett, V., McCauley, T. G.J. and Duivenvoorden, L.J. Metals in Agricultural Produce Associated with Acid Mine Drainage in Mount Morgan, Journal of Environmental Science and Health. Vol 5, No. 1, pp.561-570, 2016

[27] Bolton, B., Kundapen, H., Miller, S., Rumble, C., Jeffery, J. Acid Rock Drainage at the OK Tedi Mine, Papua New Guinea. In: Proceedings of Ninth AusIMM Open Pit Operators' Conference, 2016

[28] Andrina, J., Miller, S.C. and Neale, A.R. Performance of the Acid Rock Drainage Mitigation Waste Rock Trial Dump at Grasberg Mine 1. In Proceedings of ICARD, March 26-30, 2006, St Louis Mo.

[29] "In Situ Treatment of Acid Mine Drainage-EPA (2000)". https://cfpub.epa.gov, Accessed on January 30, 2020

[30] Mackenzie, B. Final Report: "In Situ Treatment of Acid Mine Drainage". BurnettEngineeringinc.com, Accessed on January 25, 2020

[31] Skousen, J.G., Sexstone, A. and Ziemkiewicz, P. Acid mine drainage control and treatment. $p$. 131-168. In: Reclamation of Drastically Disturbed Lands. 2nd Ed. American Society of Agronomy. Madison, WI., 2018 